\title{
Comparison of the practical usefulness of the EORTC QLQ-C15 PAL and QLQ-C30 questionnaires on the quality of life of patients with pancreatic adenocarcinoma: estimation - preliminary study report
}

\author{
JAROSŁAW DROBNIK ${ }^{1, A, D}$, FELIKS BŁASZCZYK ${ }^{2, A, B, D}$, PIOTR NOWAK ${ }^{3, A, c, D}$,
} BOGUSŁAW BECK ${ }^{4, D, F}$, ROBERT SUS ŁO ${ }^{1, D-F}$

\author{
${ }^{1}$ Department of Gerontology, Department of Public Health, Faculty of Health Sciences, Wroclaw Medical University, \\ Poland \\ ${ }^{2}$ Lower Silesian Oncology Center, Palliative Medicine Ambulatory and Home Hospice, Wroclaw, Poland \\ ${ }^{3}$ Statistics and Operational Studies Department, Economic Sciences Institute, Law, Administration and Economy \\ Faculty, University of Wroclaw, Poland \\ ${ }^{4}$ Department and Clinic of Internal and Occupational Diseases and Hypertension, Wroclaw Medical University, \\ Poland
}

A - Study Design, B - Data Collection, C - Statistical Analysis, D - Data Interpretation, E - Manuscript Preparation, F - Literature Search, G - Funds Collection

Summary Background. There are several quality of life measuring questionnaires designed for patients with cancer and who are subjected to palliative therapy. The QLQ-C30 questionnaire consists of 30 questions referring to different aspects of the patient's life; the abridged QLQ-C15 PAL questionnaire consists of half of them.

Objectives. The aim of the study was to find out whether or not the information acquired from 15 questions subtracted from the questionnaire QLQ-C30 in the process of designing its shortened version, the QLQ-C15 PAL, delivers additional practical useful information about the quality of life of patients with pancreas cancers for the purpose of palliative care.

Material and methods. A group of 38 patients with advanced stage pancreas adenocarcinoma subjected to palliative care outside hospitals in the Lower Silesia region of Poland in the years 2010-2011 was surveyed using the Polish translation of the QLQ-C30 questionnaire. The answers to 15 questions absent from the QLQ-C15 PAL questionnaire were analyzed separately.

Results. The questions removed from QLQ-C30 questionnaire in order to build up the QLQ-C15 PAL questionnaire are those which further increased the knowledge about a patient's signs and symptoms or indicate a graver status of the patient. The QLQ-C15 PAL questionnaire lacks the block of questions that the QLQ-C30 questionnaire asks about the interference of the patient's physical condition or medical treatment with family life, social activities and financial status.

Conclusions. The questions present in QLQ-C15 PAL questionnaire provide crude but complete information about the basic factors influencing a patient's quality of life that are enough for a palliative care physician to begin with when collecting or recollecting a medical history and determining or reviewing the physical status of the patient in order to adjust palliative treatment.

Key words: quality of life, palliative care, questionnaire study, pancreatic adenocarcinoma.

Drobnik J, Błaszczyk F, Nowak P, Beck B, Susło R. Comparison of the practical usefulness of the EORTC QLQ-C15 PAL and QLQ-C30 questionnaires on the quality of life of patients with pancreatic adenocarcinoma: estimation - preliminary study report. Fam Med Prim Care Rev 2017; 19(3): 209-213, doi: https://doi.org/10.5114/fmpcr.2017.69276.

\section{Background}

Patients with cancer and who are subjected to palliative therapy experience problems similar to chronically ill and elderly patients - they suffer from prolonged stress and physical symptoms, have to rely heavily on medical staff, they often feel lonely, and they have financial problems. These patients need multi-level medical and social support, which is generally insufficient in Poland [1], to a large part because of inadequate financial coverage [2] and improper systemic design [3]. This is even more disturbing, as proper care not only improves treatment results and prolongs survival time, but it also limits medical care costs [4]. The modern medicine-based approach, which is still focused on meeting the objective therapeutic criteria rather than on improving patients' quality of life, is considered to be unsatisfactory by many patients with cancer [5], and thus many of them seek complementary alternative medicine support [6]. Improper management of the patient's stress can become a source of serious problems [7], which in many cases can result in ethanol abuse [8], chronic dependency on drugs [9] and accidental or intentional overdoses [10], as well as other forms of attempted suicide or demand for euthanasia [11]. To avoid such situations, close attention must be paid - by both palliative medicine specialists and primary care physicians - to the patient's physical and mental status, and psychological and psychiatric intervention has to be undertaken immediately when needed [12]. All these factors make estimating quality of life one of the crucial parts of a medical examination [5], making it possible to efficiently and economically deal with different aspects of a patient's suffering - especially those relatively easy to manage, including pain, dyspnea [13] and nutritional deficiencies [14]. 
Although a simple rating of the quality of life by asking a single question concerning this was a popular and, initially, quite effective approach $[15,16]$, it provides only general information, while the physician taking care of a patient needs a far more detailed approach, as quality of life has many dimensions that can be positively or negatively influenced by both the illness and the therapy [16]. This is consistent with the modern holistic approach, both to health and medical care, which has made the patient's subjective improvement become one of the cornerstones of therapeutic success $[16,17]$. Questionnaires are one of the established methods for evaluation of quality of life. They can be divided into generic and cancer-specific. Among the former are: the Sickness Impact Profile (SIP), the Nottingham Health Profile (NHP), the World Health Organization Quality of Life Questionnaire and the Medical Outcomes Study Short-Form Health Survey (SF-36). Among the latter, the most renowned are: the Functional Living Index-Cancer (FLIC), the Edmonton Symptom Assessment Scale (ESAS), the Rotterdam Symptom Checklist (RSCL), the Cancer Rehabilitation Evaluation System (CARES), the Functional Assessment of Cancer Therapy (FACT-G) and the European Organization for Research and Treatment of Cancer Core Quality of Life Questionnaire (EORTC QLQ-C30) [16]. The EORTC QLQ-C30 questionnaire was initially created for the purposes of clinical trials and has been evolving and expanding for over two decades now, going through three main versions and gaining many approaches of analysis and sets of reference values [18]. Specialist modules are also being introduced that are intended to be used for various groups of patients, most recently including one under development: the module for pancreatic cancer EORTC QLQ-PAN26 [19] (although the need for this was widely noticed 15 years ago) [20]. The abbreviated version of the QLQ-C30, the QLQ-C15 PAL, is supposed to primarily serve the purposes of palliative care. Interpretation of the collected data is difficult, and there are currently many approaches: reporting the percentage of cases that belong to the given category of problems; referring against normative data collected from a healthy comparison group or from a group of patients with different diagnosis; measuring minimal changes that patients consider important; anchored interpretations comparing changes in quality of life scores against chosen clinical changes; and advanced statistical analysis, including distribution and standard deviation-based derivatives. In the clinical environment, one of many opportunities to incorporate quality of life assessment into medical practice is palliative care, in which improved quality of life is one of the principal aims of intervention, which is also an important endpoint in the case of a clinical trial [16].

\section{Objectives}

The aim of the study was to verify if the information acquired from the 15 questions - which were subtracted from the original QLQ-C30 questionnaire in the process of designing its shortened version, the QLQ-C15 PAL - delivers additional practical useful information about the quality of life of patients with pancreas cancers and which would be useful for the purpose of improvement of palliative care. The results were analyzed following the classic quality of life evaluation approach: reporting the percentage of cases that belong to the given category of problems.

\section{Material and methods}

Patients subjected to palliative care outside hospitals in the Lower Silesia region of Poland in the years 2010-2011 were surveyed routinely during palliative care visits using the Polish translation of the QLQ-C30 questionnaire. The QLQ-C30 questionnaire consists of 30 questions concerning different aspects of the patient's life, and its abridged version, the QLQ-C15 PAL questionnaire, consists of 15 key questions. Questionnaires collected from 38 patients with advanced stage pancreatic adenocarcinoma were chosen for analysis - apart from the diagnosis of wide-spread pancreatic adenocarcinoma confirmed by needle biopsy or microscopic examination, which qualified the patient for palliative care, no other entry criteria were used. The questionnaire was filled out once by each participating patient, and the process was assisted by medical staff members familiar with the demands of the protocol, who provided explanations to patients when needed. The data spreadsheet was analyzed using Microsoft Excel 2007 software - the answers to 15 questions absent in the QLQ-C15 PAL questionnaire were analyzed separately and compared against the information derived from the questions that were common for both questionnaires.

\section{Results}

Among the patients questioned, 15 (39\%) declared not having any trouble taking a short walk, only $3(8 \%)$ patients declared not having any trouble with taking a long walk, and $2(5 \%)$ of the patients declared not having any trouble doing strenuous activities, like carrying a heavy shopping bag or a suitcase. There were $26(68 \%)$ patients not requiring any help with eating, dressing, washing or using the toilet, with $4(11 \%)$ of them not having to stay in bed or sit in an armchair during the daytime. To the contrary, 5 (13\%) of the patients declared having very much trouble with taking a short walk, $10(26 \%)$ with a long walk, and 19 (50\%) with doing strenuous activities. Among the surveyed patients, 1 (3\%) declared that they need very much help with basic everyday activities, and $7(18 \%)$ stated that they are practically bedridden.

There were $24(63 \%)$ patients having no breathing difficulties in the previous week, and $3(8 \%)$ complaining about such difficulties very much. Pain was absent only in $2(5 \%)$ of patients, and $7(19 \%)$ reported suffering very much in the previous week. $5(14 \%)$ of the surveyed patients had no difficulties in sleeping, and $7(18 \%)$ of them had very much trouble sleeping. Weakness was absent in $3(8 \%)$ of patients in the previous week, and $8(21 \%)$ of them complained about feeling weak very much. Consequently, $6(16 \%)$ of patients were very much limited in doing either their work or other daily activities, and 10 (26\%) were not limited at all. The limitations in pursuing hobbies or other leisure time activities were absent in $12(31 \%)$ of patients, and $7(18 \%)$ suffered from such limitations very much. Rest was not needed by 2 (5\%) of the patients, and 14 (37\%) of them needed it very much.

During the previous week, a good appetite was present in $14(37 \%)$ of the patients, whereas $6(16 \%)$ of them lacked an appetite very much. 17 (45\%) of the patients did not suffer from nausea, and 2 (5\%) of them felt nauseated very much. 24 (63\%) of the patients did not vomit at all, and $1(3 \%)$ of them vomited very much. Constipation was a serious problem for $5(13 \%)$ of the patients, while $16(42 \%)$ of them had no such issues at all. $1(3 \%)$ of the surveyed patients declared suffering from diarrhea very much, and 23 (61\%) of them had no diarrhea.

Tiredness was a big problem for 9 (24\%) of the surveyed patients, and $1(3 \%)$ of them declared not feeling tired at all during the previous week. Pain interfered with daily activities very much in the case of $5(13 \%)$ of the patients, and no such interference was declared by $6(16 \%)$ of them. Difficulties in concentration constituted a big problem for $4(11 \%)$ of the patients, and $14(37 \%)$ had no such problem at all.

Among the surveyed patients, $3(8 \%)$ felt very tense during the previous, and 12 (31\%) did not suffer from tension; 4 (11\%) of the patients declared feeling depressed, and $5(13 \%)$ of them did not have this problem. Irritation constituted a big problem for $4(11 \%)$ of the patients, and $8(21 \%)$ were irritation free; 6 (16\%) of the patients worried very much, and $4(11 \%)$ did not worry at all. Difficulties with remembering things were reported as very troubling by $2(5 \%)$ of the patients, and $18(47 \%)$ of them denied their presence. 
Physical condition or medical treatment interfered very much with the family lives of $3(8 \%)$ of the patients, and 14 (37\%) of them did not complain about this at all. The interference of physical condition or treatment with social activities was perceived as a big problem by $4(11 \%)$ of the patients, and no such problem was noticed by $14(37 \%)$ of them. Financial difficulties associated with physical condition or treatment were experienced very much by $5(13 \%)$ of the patients, and the same percentage had no such problem at all.

The patients were asked to rate their overall health during the previous week using a scale from 1 (the worse) to 7 (the best): most patients $-19(50 \%)$ - reported a grade of 4 ; a grade of 5 was chosen by $12(31 \%)$ of the patients, a grade of $3-$ by 5 (13\%), and the lowest grades of 1 and 2 were chosen by 1 (3\%) patient each.

\section{Discussion}

Questionnaires are tools both well accepted and handy to use - thus they are widely utilized in modern medicine for different purposes: from measuring students' knowledge [21] and estimating attitudes [22], through verifying various medical professionals' level of competence [23], probing for their opinions [24] and identifying their commonly accepted practices [25], to evaluating patients' health status, awareness [26], preferences and satisfaction with medical care [27]. More and more often, not only patients, but also the people supporting them, get surveyed [28]. Validation of newly developed questionnaires is a prolonged and difficult process [29], thus, for practical reasons, it is common in medical studies to use previously existing and evaluated questionnaires. This approach also makes it easier to compare the results of different studies directly.

The QLQ-C30 questionnaire aims at estimating the quality of life of patients [30] and consists of 30 questions concerning different aspects of the patient's life, making it highly detailed. Eliminating half of these questions resulted in the creation of the QLQ-C15 PAL questionnaire [31]. Surveys are extremely fast to be carried out with the concise version of the questionnaire even in case of very skeptical and uncooperative patients. Both questionnaires have undergone in-depth evaluation, proving their high efficacy and adequacy in estimating quality of life. The QLQ-C30 questionnaire is under further development, and up to present, several additional modules have been created in order to suit the needs of advanced quality of life evaluation in patients with different kinds of illnesses - the neoplastic illnesses modules that are currently in use involve: bone metastases, brain, breast, cervical cancer, colorectal, colorectal liver metastases, endometrial, gastric, head and neck, hepatocellular carcinoma, lung, multiple myeloma, neuroendocrine carcinoid, esophageal, esophago-gastric, ovarian, prostate, and there is also a special module designed for use with elderly cancer patients. Currently, there is no fully validated QLQ-C30 questionnaire extension module designed for examination of patients with pancreas cancers [30].

The QLQ-30 questionnaire's question about having trouble with strenuous activities, like carrying heavy shopping bags or taking long walks, is a further evaluation of the basic questions also present in the QLQ-C15 PAL concerning trouble with taking short walks, needing to stay in bed or in a chair during the day and needing help with basic everyday activities. The study confirmed that the QLQ-C15 PAL indicates the presence of the most limiting disabilities - but less limiting disabilities diagnosed by the QLQ-C30 were more frequent.

The questions in the QLQ-C15 PAL questionnaire pertaining to shortness of breath, having pain, feeling weak and trouble sleeping, provide knowledge about the patient's limitations in his/her overall life capacity perceiving, while the questions in the QLQ-C30 questionnaire about feeling limited in work, daily activities and hobbies, as well as about the need to rest, expand upon this. In the surveyed patients, the answers to specific questions in the QLQ-C30 were consistent with the background information provided by the QLQ-C15 PAL.

The QLQ-C15 PAL questionnaire covers basic, less intense and early symptoms - lack of appetite, nausea and constipation - whereas the QLQ-C3O also asks about vomiting and diarrhea, thus expanding knowledge about gastrointestinal tract functions and its graver disturbances, which are very important in patients with pancreatic cancer. In the group of study participants, vomiting and diarrhea were less common than the core QLQ-C15 PAL symptoms.

The QLQ-C30 questionnaire's question on concentration difficulties evaluates the practical influence of tiredness and pain interference on daily activities - which are the base topics also explored by the QLQ-C15 PAL. In the examined group of patients, problems caused by difficulties in concentration were less common than both tiredness and pain.

The QLQ-C15 PAL questionnaire asks basic questions on mental status - about tension and feelings of depression - whereas in the QLQ-C30, they are accompanied by information about feelings of worry and irritation and about difficulties in remembering things. These QLQ-C30 questions evaluate a broader range of mood disorder symptoms. The prolonged stress and depression-related set of symptoms detected by the QLQ-C30 pointed at different stages of depression development among the surveyed patients: feeling worried was more commonly present than feeling depressed; feelings of tension and irritation were as equally common as feeling depressed, and difficulties with remembering things were declared less commonly than feeling depressed.

The QLQ-C15 questionnaire lacks the block of questions the QLQ-C30 asks about interference of a patient's physical condition or medical treatment with family life, social activities and financial status - which are very important in the long run, but may not be crucial in a first-time medical evaluation. Among the study participants, illness and its treatment interfered the most with their financial status, as well as with their social and family life.

The authors did not find any similar study that would allow for a direct comparison of the results. However, a study on patients with pancreatic cancer after evaluation with the EORTC QLQ-30 and QLQ-PAN26 revealed that fatigue, loss of appetite and an impaired sense of well-being were troubling them most [32], while questionnaires for patients suffering from chronic pancreatitis revealed a fear of future health problems, sleeping difficulties and fatigue [33] - these symptoms were also present in the patients with pancreatic adenoma participating in the authors' study.

\section{Conclusions}

The study has confirmed that the questions removed from the QLQ-C30 PAL questionnaire in order to build up the QLQ-C15 PAL are those that further increase the knowledge about a patient's signs and symptoms or indicate a graver status of the patient. The questions left in the QLQ-C15 PAL provide crude but complete information about the basic factors influencing a patient's quality of life and are sufficient for a palliative care physician to adjust treatment quickly, being a valuable addition to the medical history and the patient's physical status. The QLQ-C30, used repeatedly, especially enriched with additional modules focusing on specific conditions, takes much more time; however, it is much better than the QLQ-C15 PAL and allows one to observe the changes in quality of life over long periods, to verify treatment efficacy and side-effects and to make a comparison of patient groups treated differently. This preliminary study will be continued on a larger patient group, and a cross-comparison of the QLQ-C15 PAL and QLQ-C30 with other questionnaires on quality of life is also planned, focusing on their efficacy in the evaluation of the needs of patients with pancreas cancer. 
Source of funding: This work was funded by the authors' resources.

Conflict of interest: The authors declare no conflict of interests.

\section{References}

1. Drobnik J, Susło R, Kurpas D, et al. Analiza systemu opieki nad osobami starszymi i ich potrzeb zdrowotnych na Dolnym Śląsku. Fam Med Prim Care Rev 2010; 12(2): 165-167 (in Polish).

2. Kollbek P, Lenkiewicz L, Drobnik J, et al. Analiza sposobu podziału środków Narodowego Funduszu Zdrowia i jego konsekwencji dla zaopatrzenia medycznego populacji dolnośląskiej. Probl Hig Epidemiol 2007; 88(1): $84-90$ (in Polish).

3. Thannhäuser-Wójcik A, Trnka J, Susło R. Zmiany w stacjonarnej opiece nad osobami przewlekle chorymi i umierajacymi na Dolnym Ślqsku w latach 2003-2007. In: Kolbuszewski J, ed. Problemy współczesnej tanatologii: medycyna - antropologia kultury - humanistyka. Vol. 13. Wrocław: Wrocławskie Towarzystwo Naukowe; 2009: 85-90 (in Polish).

4. Krzemieniecki K. Cancer related cachexia management - blessing for patients and curse for the National Health Fund? A critical analysis of cachexia treatment in Poland. Współcz Onkol 2008; 12(1): 38-42.

5. Farbicka P, Nowicki A. Selected aspects of palliative care and quality of life at the terminal stage of neoplastic disease. Współcz Onkol 2012; 16(6): 506-511.

6. Tarhan O, Alacacioglu A, Somali I, et al. The association of complementary alternative medicine use with anxiety, depression and quality of life in Turkish cancer patients. Wspólcz Onkol 2011; 15(5): 274-278.

7. Susło R, Trnka J, Drobnik J. Zagrożenie śmierciq jako czynnik etiologiczny zaburzeń psychicznych. In: Kolbuszewski J, ed. Problemy wspótczesnej tanatologii: medycyna - antropologia kultury - humanistyka. Vol. 12. Wrocław: Wrocławskie Towarzystwo Naukowe; 2008: 129-132 (in Polish).

8. Trnka J, Susło R, Drobnik J. Lekarz rodzinny wobec zjawiska nadużywania alkoholu przez pacjentów. Przew Lek 2010; 2: 184-187 (in Polish).

9. Susło R, Drobnik J, Trnka J. Rozpoznawanie i dokumentowanie przypadków przewlekłej intoksykacji wśród pacjentów podstawowej opieki zdrowotnej. Przew Lek 2010; 2: 180-183 (in Polish).

10. Drobnik J, Susło R, Trnka J. Ostre zatrucia substancjami psychoaktywnymi jako praktyczny problem lekarza rodzinnego. Przew Lek 2010; 2: 131-134 (in Polish).

11. Trnka J, Susło R, Drobnik J. et al. Legal-medical aspects of the euthanasia. Bad Nauk 2007; 21(2): 60.

12. Miturska H, Susło R, Drobnik J. et al. Zagadnienia etyczne i prawne w opiece psychiatrycznej. In: Kurpas D, Miturska H, Kaczmarek M, eds. Podstawy psychiatrii dla studentów pielęgniarstwa. Wrocław: Wydawnictwo Continuo; 2009: 215-233 (in Polish).

13. Kotlińska-Lemieszek A, Bączyk E, Łuczak J. Somatic aspects of suffering. Progress in relieving pain, dyspnoea and other cancer symptoms. Współcz Onkol 2000; 4(5): 224-230.

14. Gawrychowski K. Cancer-related anaemia. Współcz Onkol 2006; 6: 310-312.

15. Gough I, Funival C, Schilder L, et al. Assessment of the quality of life of patients with advanced cancer. EJC 1983; 19(8): 1161-1165.

16. Aaronson N, Fayes P. Quality of life. In: Velde J, Baumann M, eds. Oxford textbook of oncology. Oxford: Oxford University Press; 2016.

17. Karnofsky D, Abelmann W, Craver L, et al. The use of the nitrogen mustards in the palliative treatment of carcinoma. Cancer 1948; 1(4): 634-656.

18. Scott NW, Fayers PM, Aaronson NK, et al. EORTC QLQ-C30 Reference Values. Brussels: EORTC Quality of Life Study Group; $1998: 9$.

19. EORTC Quality of Life Group. Pancreatic Cancer (EORTC QLQ-PAN26) [cited 8.05.2017] Available from URL: http://groups.eortc.be/qol/ pancreatic-cancer-eortc-qlq-pan26.

20. Fitzimmons D, Johnson C, George S, et al. Development of a disease specific quality of life (QoL) questionnaire module to supplement the EORTC core cancer QoL questionnaire, the QLQ-C30 in patients with pancreatic cancer. EJC 1999; 35(6): 939-941.

21. Topczewska-Cabanek A, Nitsch-Osuch A, Gyrczuk E, et al. Wiedza i opinia studentów IV i VI roku medycyny na temat problemu przemocy w rodzinie - badanie ankietowe. Fam Med Prim Care Rev 2010; 12(3): 852-854 (in Polish).

22. Markiewicz-Górka I, Korneluk J, Pirogowicz I. Aktywność fizyczna oraz wiedza studentów Akademii Medycznej we Wrocławiu na temat jej roli w profilaktyce chorób - badanie ankietowe. Fam Med Prim Care Rev 2011; 13(3): 436-439 (in Polish).

23. Gazdecka-Szpecht K, Wawrzyniak A, Celczyńska-Bajew L, et al. Ocena poziomu wiedzy lekarzy rodzinnych na temat raka piersi na podstawie badania ankietowego. Fam Med Prim Care Rev 2008; 10(3): 408-410 (in Polish).

24. Lewek P, Śmigielski J, Kardas P. Wpływ wiedzy aptekarza na temat leków generycznych, na jego opinię o skuteczności tych leków - badanie ankietowe. Fam Med Prim Care Rev 2014; 16(2): 124-126 (in Polish).

25. Pokorna-Kałwak D, Sapilak B, Muszyńska A, et al. Nadciśnienie tętnicze u osób otyłych - charakterystyka grupy, preferencje terapeutyczne, na podstawie badań ankietowych w poradniach POZ. Fam Med Prim Care Rev 2008; 10(3): 615-617 (in Polish).

26. Topczewska-Cabanek A, Nitsch-Osuch A, Gyrczuk E, et al. The parents' awareness of the cocoon strategy - a questionnair. Fam Med Prim Care Rev 2011; 13(3): 521-523.

27. Grębowski R, Marcinowicz L. Advantages and limitations of open questions in questionnaire studies of patients' satisfaction with family doctor care. Fam Med Prim Care Rev 2009; 11(1): 26-31.

28. Topczewska-Cabanek A, Nitsch-Osuch A, Gyrczuk E, et al. Wiedza rodziców na temat strategii kokonowej - badanie ankietowe Fam Med Prim Care Rev 2009; 11(3): 521-523 (in Polish).

29. Nitsch-Osuch A, Topczewska-Cabanek A, Gyrczuk E, et al. Walidacja kwestionariusza autorskiego dotyczącego wiedzy i opinii studentów medycyny na temat problem przemocy w rodzinie. Fam Med Prim Care Rev 2008; 10(3): 575-577 (in Polish).

30. EORTC Quality of Life Group. EORTC QLQ-C30 Scoring Manual [cited 8.05.2017]. Available from URL: http://groups.eortc.be/qol/manuals.

31. EORTC Quality of Life Group. Addendum to the EORTC QLQ-C30 Scoring Manual: Scoring of the EORTC QLQ-C15-PAL [cited 8.05.2017]. Available from URL: http://groups.eortc.be/qol/eortc-qlq-c15-pal.

32. Fitzimmons $D$, Kahl S, Butturini G, et al. Symptoms and quality of life in chronic pancreatitis assessed by structured interview and the EORTC QLQ-C30 and QLQ-PAN26. Am J Gastroenterol 2005; 100(4): 918-926.

33. Labori $\mathrm{K}, \mathrm{Hjermstad} \mathrm{M}$, Wester T, et al. Symptom profiles and palliative care in advanced pancreatic cancer - a prospective study. Support Care Cancer 2006; 14(11): 1126-1133.

Tables: 0

Figures: 0

References: 33 
Received: 11.04.2017

Revised: 01.06.2017

Accepted: 30.06 .2017

Address for correspondence:

Feliks Błaszczyk, MD

Dolnośląskie Centrum Onkologii

pl. Hirszfelda 12

53-413 Wrocław

Polska

Tel.: +48 602 478-182

E-mail: onc@hot.pl 